Original article

\title{
Developmental patterns of leaves and tillers in a black-grass population (Alopecurus myosuroides Huds.)
}

\author{
Bruno Chauvel*, Nicolas Munier-Jolain, Anne Letouzé, David Grandgirard
}

Unité de Malherbologie et Agronomie, INRA, 17 rue Sully, BP 1540, 21034 Dijon Cedex, France

(Received 28 July 1999; revised 16 December 1999; accepted 18 January 2000)

\begin{abstract}
In an agricultural system with low herbicide input, prediction of the timing of annual weed developmental stages would be useful to predict weed growth rate and seed production, or to determine the appropriate timing for the application of foliar herbicides in order to optimize their use and avoid secondary effects of herbicide treatment such as water pollution or herbicide resistance. A model based on thermal time with a $1{ }^{\circ} \mathrm{C}$ base temperature has been proposed to describe the rate of appearance of leaves and tillers on the main stem of black-grass (Alopecurus myosuroides Huds.). Our data suggest that the variability in developmental rate is relatively low between plants within a trial, but that the leaf appearance rate varies according to the sowing dates and the growth conditions. According to the sowing dates, phyllochron values vary from 60 to 99 degree days per leaf, whereas tiller developmental rates vary from 66 to 95 degree days. The combined action of cumulative radiation and photoperiod can modify phyllochron values. According to the date of emergence in the field, two different phyllochron values apparently describe black-grass development rates for the population in this study.
\end{abstract}

Alopecurus myosuroides Huds. / weed / development / phyllochron / base temperature

Résumé - Schéma d'émission des feuilles et des talles chez une population de vulpin (Alopecurus myosuroides Huds.). Dans des systèmes de culture à faibles niveaux d'intrants en herbicides, la connaissance de la vitesse de développement d'une plante annuelle adventice serait utile pour prévoir sa croissance et sa production de semences, ainsi que pour déterminer les dates optimales d'application des herbicides foliaires afin d'éviter les problèmes liés à leur utilisation tels que la pollution des nappes ou le développement de populations résistantes. Un modèle basé sur une échelle de temps thermale avec une température de base de $1{ }^{\circ} \mathrm{C}$ est proposé pour décrire l'apparition des feuilles et des talles sur le brin-maître du vulpin (Alopecurus myosuroides Huds.). Nos données suggèrent que la variabilité de développement est faible entre les plantes pour une expérimentation donnée, mais que l'apparition des feuilles varie de façon importante entre expérimentations selon les dates de semis et les conditions de croissance. Selon la date de semis, le

Communicated by Cesar Fernandez-Quintanilla (Madrid, Spain)

* Correspondence and reprints

chauvel@dijon.inra.fr 
phyllochrone est compris entre 60 et $99^{\circ} \mathrm{C}$ par feuille, alors que de 66 à $95{ }^{\circ} \mathrm{C}$ sont nécessaires pour l'apparition d'un nouveau talle primaire. L'action combinée du rayonnement global et de la photopériode modifie les valeurs de phyllochrone observées. Selon les dates d'émergence au champ, deux valeurs différentes de phyllochrone peuvent être retenues pour décrire le taux d'apparition des feuilles du vulpin pour la population étudiée.

Alopecurus myosuroides Huds. / mauvaise herbe / développement / phyllochrone / température de base

\section{Introduction}

Since 1960, black-grass (Alopecurus myosuroides Huds.) has been a common annual grass weed in autumn-sown crop rotations in Atlantic European countries. Intensive cultural practices seem to have contributed to the spread of this species, which is characterized by a high reproductive capacity of relatively non-dormant seeds. In most cases, black-grass has only been controlled by intensive chemical treatments, which in recent years have unfortunately induced the successive development of different herbicide-resistant populations [18, 33]. However, control of the weed populations can be obtained by cultural practices, associated with appropriate herbicide treatments, in order to limit weed growth and reduce seed production [35].

As for other annual weeds, seed production is the only way for black-grass population survival and propagation. A knowledge of the biology of this weed would, therefore, be useful for predicting its field response according to climatic conditions and cropping systems. Although some demographic models on black-grass have appeared in the literature [11, 34, 44], very little investigation has been carried out on the effects of cultural practices on its development and growth. In fact, as for other grass weeds, data have been collected on black-grass biology and ecology [5, 34, 36, 41], but little research has been conducted on its development and growth requirements. Furthermore, these results are not easy to interpret for modelization due to the high variability in the response of this species, and either a lack of information about, or too much variability regarding growth conditions.
The objectives of the present study were to evaluate, for one black-grass population, patterns and variability in its development by documenting the rates of appearance of leaves and primary tillers on the main stem. The variations among rates were determined for a range of growth temperatures and photoperiods obtained by different sowing dates both in the field and in the greenhouse. A daily thermal time scale was used for assessing weed development. First, we assessed the phyllochron and the rate of tillering according to temperature, and then compared the black-grass development described by the relationship between the main stem development and primary tiller appearance to the models developed for cultivated grass crops such as wheat.

\section{Materials and methods}

The black-grass population studied was collected in a wheat field in the north of France (Department of Pas de Calais, $50^{\circ} 3^{\prime} \mathrm{N}, 2^{\circ} 1^{\prime} \mathrm{E}$ ) in 1994. Seeds were harvested in the field from at least 50 randomly chosen ripened ears. All studies were conducted from this seed stock containing about $150 \mathrm{~g}$ of spikelets (about 100000 spikelets [12]).

Trials were conducted in the field and in the greenhouse (Tab. I). For the greenhouse trials, 3-g samples of wet seeds were vernalized in a fridge for 3 weeks at $4{ }^{\circ} \mathrm{C}$ in the darkness. Six seeds were sown 1 centimeter $(\mathrm{cm})$ deep in pots (diameter: $7 \mathrm{~cm}$, volume: $1 \mathrm{~L}$ ) filled with sandy clay soil. Pots were distributed randomly in the greenhouse with 44 pots per square meter. Seedlings were thinned 
Table I. Description of the trials set up to study developmental processes in black-grass.

\begin{tabular}{|c|c|c|c|c|c|c|}
\hline Trial No. & $\begin{array}{c}\text { Emergence } \\
\text { date }\end{array}$ & $\begin{array}{c}\text { End of } \\
\text { development } \\
\text { measures }\end{array}$ & $\begin{array}{c}\text { Mean } \\
\text { temperature } \\
\left({ }^{\circ} \mathrm{C}\right)\end{array}$ & $\begin{array}{l}\text { Mean } \\
\text { radiation } \\
\left(\mathrm{MJ} / \mathrm{m}^{2}\right)\end{array}$ & $\begin{array}{l}\text { No. } \\
\text { of plants } \\
\text { studied }\end{array}$ & $\begin{array}{l}\text { Type of } \\
\text { trial }\end{array}$ \\
\hline 1 & January 96 & April 97 & 13.6 & 805 & 160 & Greenhouse \\
\hline 2 & March 96 & June 97 & 18.2 & 1867 & 280 & Greenhouse \\
\hline 3 & August 96 & April 97 & 7.2 & 813 & 15 & Field \\
\hline 4 & October 96 & April 97 & 5.8 & 727 & 15 & Field \\
\hline 5 & November 96 & May 97 & 6.4 & 929 & 15 & Field \\
\hline 6 & March 97 & June 97 & 12.6 & 1693 & 15 & Field \\
\hline 7 & March 97 & June 97 & 12.9 & 1759 & 15 & Field \\
\hline 8 & April 97 & July 97 & 14.7 & 1845 & 15 & Field \\
\hline 9 & May 97 & August 97 & 17.5 & 1853 & 15 & Field \\
\hline 10 & May 97 & August 97 & 18.2 & 1876 & 15 & Field \\
\hline 11 & January 98 & April 98 & 13.6 & 935 & 40 & Greenhouse \\
\hline 12 & December 97 & May 98 & 7.2 & 922 & 20 & Field \\
\hline 13 & March 98 & June 98 & 13.1 & 1640 & 20 & Field \\
\hline
\end{tabular}

to 1 per pot at the first leaf stage. Only seedlings that had emerged on the same date were retained to obtain a uniform date of emergence for each trial. Plants were watered twice daily with Hoagland nutrient solution. Because of the spacing between pots, competition for light between plants due to leaf interception was very low before stem elongation. In the greenhouse, the appearance of leaves (between leaf numbers 2 and 7) and primary tillers (between tiller numbers 1 and 6) on the main stem was recorded daily. Coleoptile tillers were observed in a very few cases. Temperature regimes and photoperiods were natural, with a minimum temperature of $10{ }^{\circ} \mathrm{C}$. To minimize the effects of light and temperature variability in the greenhouse, pots were rotated each week.

The second set of trials was conducted in the field (INRA Experimental Station in Dijon; $\left.47^{\circ} 20^{\prime} \mathrm{N}, 5^{\circ} 2^{\prime} \mathrm{E}\right)$. A range of growth temperatures and photoperiods was obtained by varying the sowing date (Tab. I). For each sowing date, seeds were sown in 15 clusters in a row $30 \mathrm{~cm}$ apart. Each cluster consisted of 10 seeds; seedlings were quickly thinned to one (2-leaf stage) after emergence to avoid competition for light. Plants were watered once a week. In the field trials, emergence of leaves and tillers on the main stem was recorded periodically 2 to 3 times a week. Both in the field and in the greenhouse, a new leaf was recorded when its lamina tip was observed pointing over the ligule of the last leaf.

Accumulated degree days (the sum of mean daily temperatures minus the base temperature) from seedling emergence were calculated using air temperatures obtained directly in the greenhouse and from a local weather station less than $1 \mathrm{~km}$ away from the site of the field experiment. Global solar radiation was measured with a pyranometer (CIMEL CE-180).

The base temperature suitable for describing black-grass development was estimated using the least variability method $[3,14,23]$. A range of base temperatures from -5 to $+7{ }^{\circ} \mathrm{C}$ was tested in $1{ }^{\circ} \mathrm{C}$ increments. For each trial and for each base temperature, the phyllochron (time between visual appearance of successive leaves) was determined, and the base temperature selected was that for which the coefficient of variation of the phyllochron was the lowest. The same base temperature determined for the phyllochron was used for calculation of the rate of tiller appearance.

Rates of leaf and tiller appearance were calculated plant by plant to obtain a mean rate for each trial. The effects of growth conditions were compared using the general model linear procedure 
(GLM procedure), using the Student-NewmanKeuls multiple range test with SAS statistical software [39].

\section{Results}

\subsection{Determination of base temperature}

For the thermal time scale, a simple linear model could be used to describe developmental processes in black-grass (Fig. 1).

According to the least variability method [3], the base temperature determined in the studied blackgrass populations in the various trials was $1{ }^{\circ} \mathrm{C}$ (Fig. 2).

\subsection{Variability}

To compare tiller and leaf appearance in the different experiments, we estimated the thermal time (in ${ }^{\circ} \mathrm{C}$, base temperature of $1{ }^{\circ} \mathrm{C}$ ) required for the appearance of each leaf (between leaf numbers 2 and 7) and tiller (between tiller numbers 1 and 6 , when possible). The rate of appearance of leaves and tillers varied between 59 to $98{ }^{\circ} \mathrm{C}$ and 62 to $95{ }^{\circ} \mathrm{C}$ respectively (Tab. II). The variability was low between plants within a trial, but environmental conditions appeared to strongly influence developmental processes in black-grass; i.e., leaf appearance was always a linear function of thermal time, but the slope of the relation depended on growth conditions and emergence dates in the trial (a)

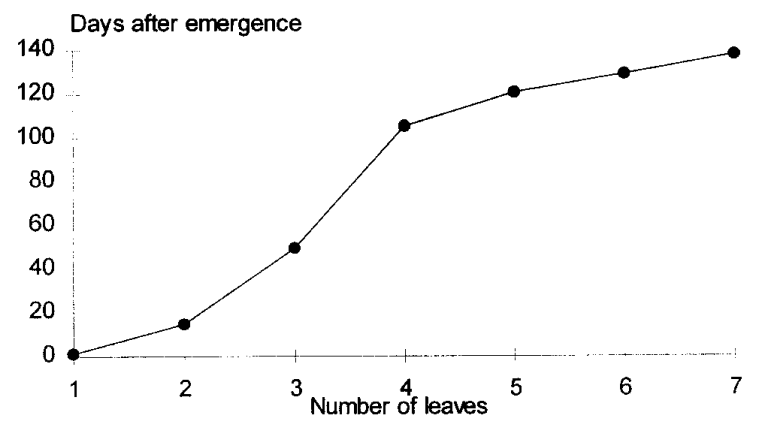

(b)

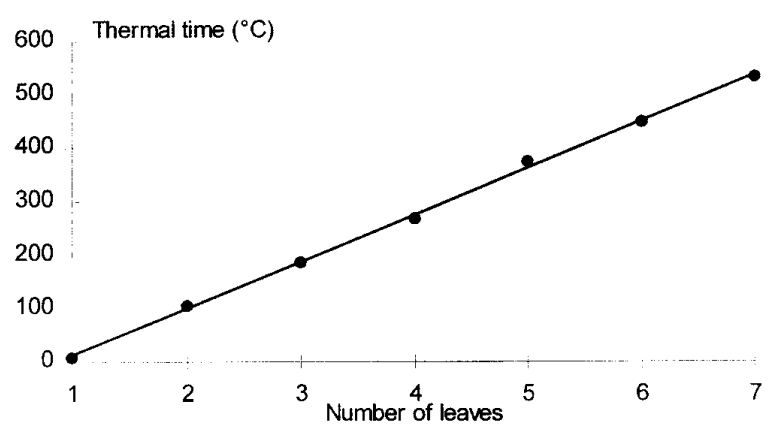

Figure 1. Emergence of leaves according to (a) a day-time scale and (b) a thermal-time scale, in trial 5. A linear model was fitted to data in $(\mathbf{b})\left(\mathrm{y}=87.29 \mathrm{x}-74.23 ; \mathrm{r}^{2}=0.99\right)$.

(Fig. 3). Black-grass phyllochron variability could be explained by environmental factors. In the field, leaf appearance rate decreased when the emergence date was delayed from February to November (Fig. 4). Nevertheless, phyllochron

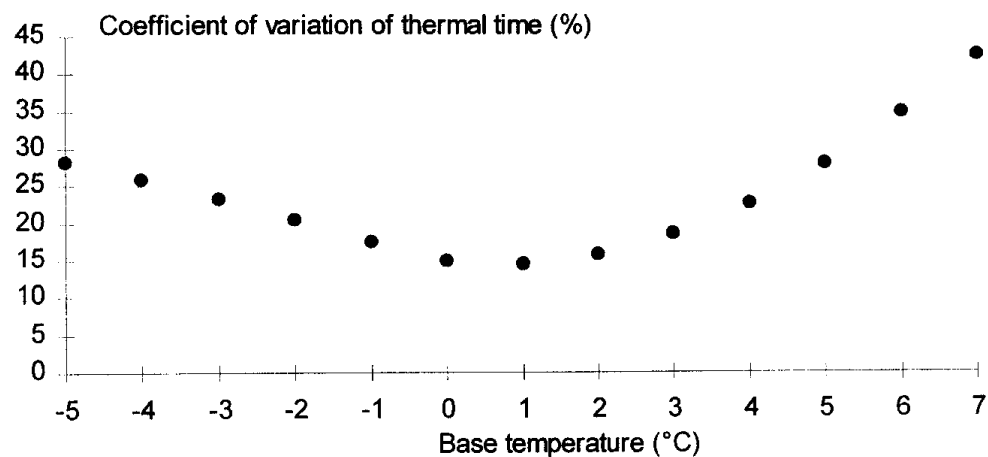

Figure 2. Coefficient of variation of thermal time for phyllochrons of leaves on the main stem of black-grass according to the base temperature selected in the calculation. 
Table II. Mean values for rate of organ appearance (in degree days, base temperature of $1{ }^{\circ} \mathrm{C}$ ). Values followed by different letters are significantly different at $\mathrm{P}=0.05$ as determined by Student-Newman-Keuls test.

\begin{tabular}{|c|c|c|c|c|c|c|}
\hline Trial No. & $\begin{array}{c}\text { Time between } \\
\text { two leaves } \\
\text { appearance } \\
\left({ }^{\circ} \mathrm{C} / \text { leaf }\right)\end{array}$ & $\begin{array}{l}\text { Standard error } \\
\text { of the mean }\end{array}$ & & $\begin{array}{c}\text { Time between } \\
\text { two tillers } \\
\text { appearance } \\
\left({ }^{\circ} \mathrm{C} / \text { tiller }\right)\end{array}$ & $\begin{array}{l}\text { Standard error } \\
\text { of the mean }\end{array}$ & \\
\hline 1 & 98.77 & 1.83 & $\mathrm{a}$ & 85.16 & 1.68 & $a b$ \\
\hline 2 & 78.76 & 1.13 & $\mathrm{c}$ & 79.93 & 1.29 & $\mathrm{bc}$ \\
\hline 3 & 78.57 & 3.51 & $\mathrm{c}$ & 89.80 & 4.57 & $a b$ \\
\hline 4 & 78.90 & 1.79 & $\mathrm{c}$ & 95.03 & 3.80 & $\mathrm{a}$ \\
\hline 5 & 87.64 & 2.56 & $\mathrm{~b}$ & 93.63 & 3.88 & $\mathrm{a}$ \\
\hline 6 & 65.20 & 1.36 & de & 67.72 & 3.27 & $\mathrm{de}$ \\
\hline 7 & 59.43 & 1.84 & $\mathrm{e}$ & 66.30 & 2.67 & $\mathrm{de}$ \\
\hline 8 & 63.63 & 2.06 & de & 66.44 & 2.31 & $\mathrm{de}$ \\
\hline 9 & 70.06 & 1.24 & $\mathrm{~d}$ & 71.71 & 3.50 & cde \\
\hline 10 & 76.59 & 2.41 & $\mathrm{c}$ & 79.55 & 2.99 & $\mathrm{bc}$ \\
\hline 11 & 88.56 & 1.02 & $\mathrm{~b}$ & 94.70 & 1.33 & $\mathrm{a}$ \\
\hline 12 & 71.04 & 2.05 & $\mathrm{~d}$ & 61.80 & 3.56 & $\mathrm{e}$ \\
\hline 13 & 63.63 & 1.80 & de & 74.20 & 2.86 & $\mathrm{~cd}$ \\
\hline
\end{tabular}

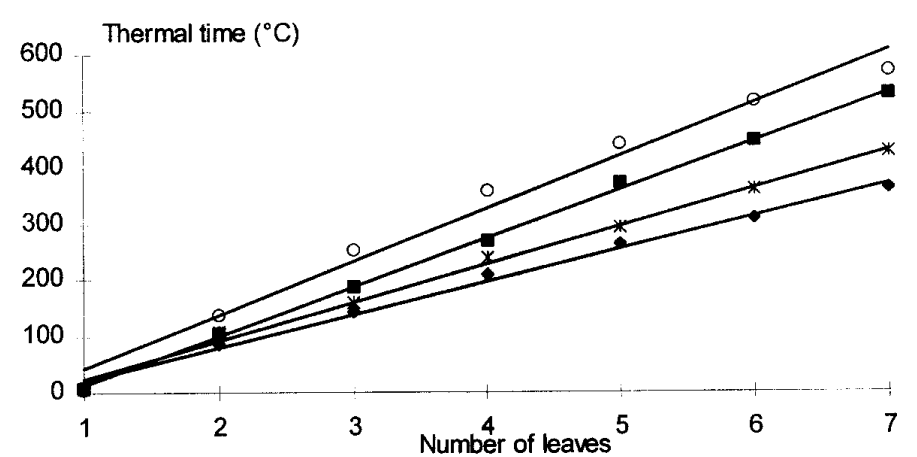

7
Figure 3. Relationship between leaf number and time of emergence (thermal scale ${ }^{\circ} \mathrm{C}$, base temperature of $1{ }^{\circ} \mathrm{C}$ ) for trial 1: $\bigcirc$; trial 5: $\mathbf{\square}$; trial 7: $\diamond$; trial 9: $*$. Fitted equations were as follows: trial $1: \mathrm{y}=94.51 \mathrm{x}-51.86$, $\mathrm{r}^{2}=0.98$; trial 5: $\mathrm{y}=87.29 \mathrm{x}-74.23, \mathrm{r}^{2}=0.99$; trial 7: $\mathrm{y}=58.50 \mathrm{x}-38.50, \mathrm{r}^{2}=0.99 ;$ trial $9: \mathrm{y}=67.92 \mathrm{x}-43.94$,
$\mathrm{r}^{2}=0.99$.

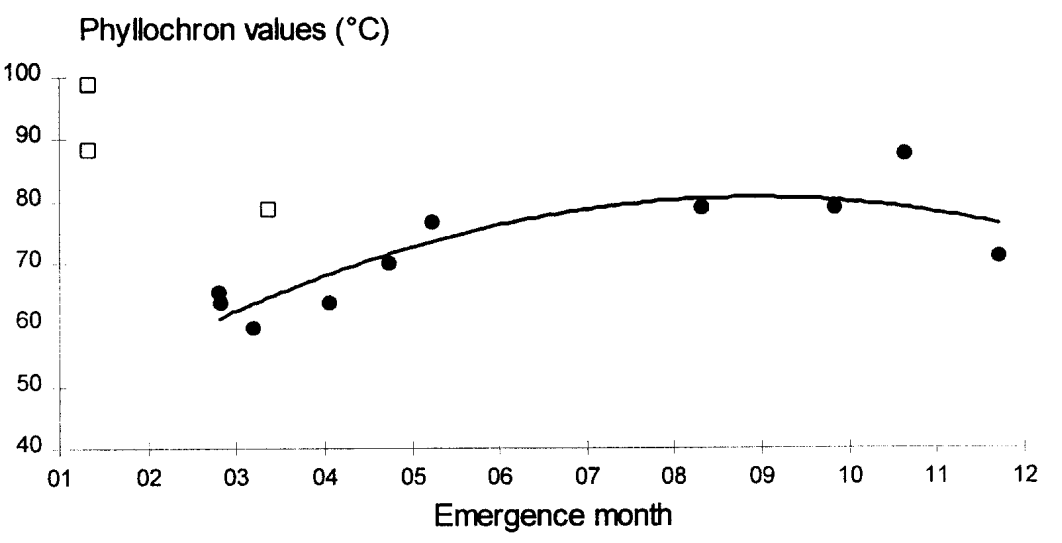

Figure 4. Relationship between phyllochron values and month of emergence (field trials: $\mathbf{0}$; greenhouse trials: $\square$ ). 


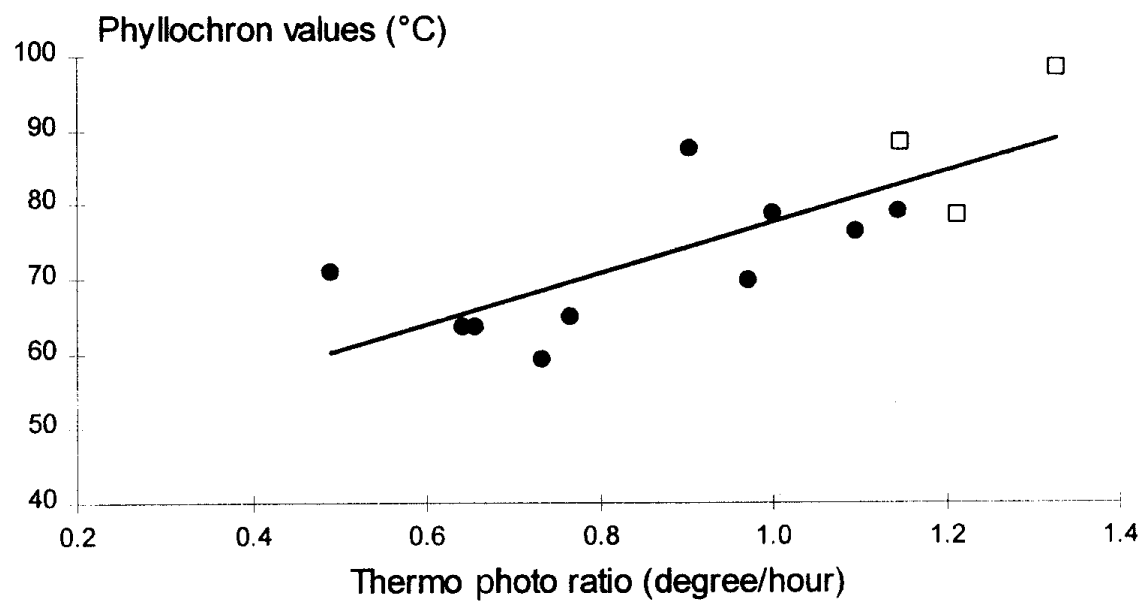

Phyllochron values $\left({ }^{\circ} \mathrm{C}\right)$

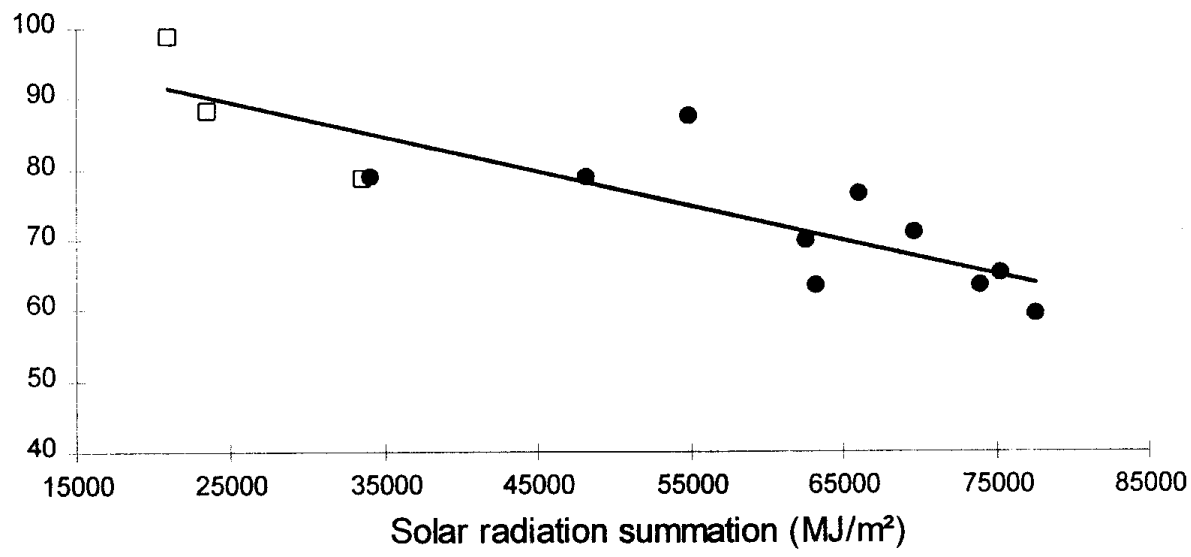

Figure 5. Relationship between phyllochron and thermo/photo ratio (in degree/hour) (field trials: $\mathbf{0}$; greenhouse trials: $\square$ ). Fitted equation was $\mathrm{y}=34.57 \mathrm{x}+43.51, \mathrm{r}^{2}=0.59$.

Figure 6. Relationship between phyllochron values and cumulative solar global radiation between leaves 2 and 7 (field trials: $\bigcirc$; greenhouse trials: $\square$ ). Fitted equation was $\mathrm{y}=-0.005 \mathrm{x}$ $+101.84, r^{2}=0.72$.

values for greenhouse trials apparently did not respond in the same way. As phyllochron variability is poorly related with photoperiod (data not shown), phyllochron values were analyzed in terms of the ratio of temperature to photoperiod [7] (Fig. 5). Data from the greenhouse and from the field responded in the same way, but the correlation was low $\left(\mathrm{r}^{2}=0.59\right)$. A better relationship was obtained for data from all the experiments when global solar radiation (cumulative radiation between emergence to leaf number $7 ; \mathrm{r}^{2}=0.72$ ) was used (Fig. 6); i.e., phyllochron values decreased with the quantity of radiation accumulated during this stage of development. From these different results, it appeared that two different phyllochron values could be used to predict blackgrass development in the field for this population according to the season in the field (Fig. 4). About $80{ }^{\circ} \mathrm{C}$ were necessary to develop a new leaf under low cumulative radiation conditions and a decreasing photoperiod (as for black-grass seedlings in a winter crop), and about 65 degree days were necessary under increasing light conditions and high cumulative radiation (as for black-grass seedlings in spring crops). Our results suggest that the combined action of environmental factors (temperature, radiation and daylength) could directly or indirectly influence black-grass leaf appearance. 


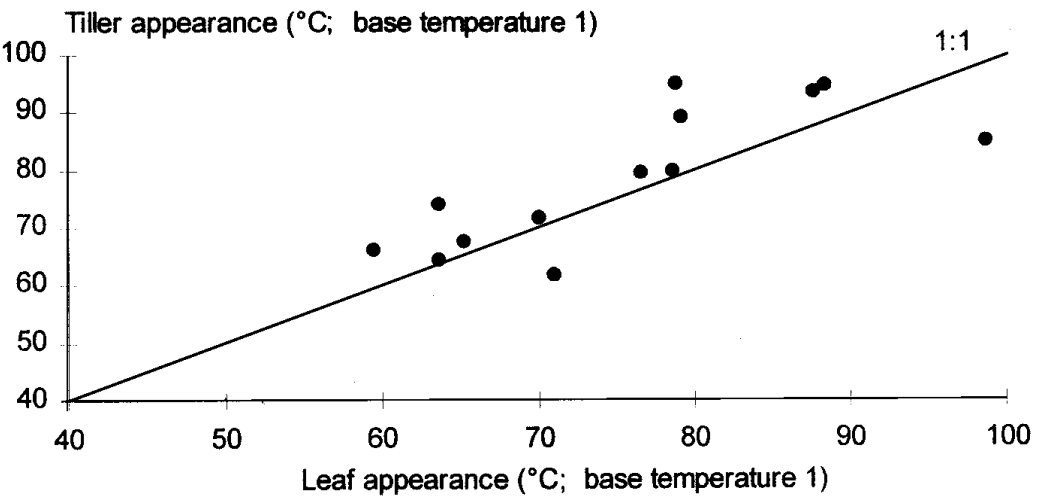

Figure 7. Relationship between tiller appearance and leaf appearance (in ${ }^{\circ} \mathrm{C}$, base temperature of $1{ }^{\circ} \mathrm{C}$ ).

\subsection{Relationship between leaf and tiller appearance}

The observed values of tiller appearance tended to be higher than phyllochron values (Fig. 7). Nevertheless, the observed relationship ( $\mathrm{y}=0.80 \mathrm{x}$ $+18.84)$ was not statistically different to the bisectrix.

For the greenhouse experiments (trials 1, 2 and 11 , in which conditions were more controlled), we compared primary tiller appearance on the main stem in comparison with leaf appearance. For these 3 experiments, the same relationship was observed between leaves and tillers (Fig. 8): the first tiller appeared when its subtending leaf and about two and a half subsequent leaves were expanded. Afterwards, 1 tiller appeared for every expanding leaf. The same relationship has been observed under field conditions for the first levels of leaves.

\section{Discussion}

Few models in the literature describe annual weed developmental processes using cumulative temperature or temperature thresholds when compared with the numerous models that have been used to describe crop species [20, 22, 25], forage grasses [16], insect pests [38] or parasites [1].

Heat unit accumulation or temperature optima are rarely used to describe weed demography.
Nevertheless, development of sustainable agriculture will require such approaches to develop longand short-term strategies for pest management [19]. Weeds are certainly among the major limiting factors for this type of agriculture due to the longterm effects of cultural practices on the seed bank. To incorporate black-grass developmental processes into any model of crop development would help to improve our understanding of the interactions between cereal crops and this weed, and thereby prevent weed infestation. Cultural practices such as crop cultivar choice or sowing date could be improved by models that simulate weed growth. Although in the literature on weeds data or models can be found such as threshold temperature for seed germination requirements [23, 43], rhizome development [24, 40], or vegetative growth [6], they are not conventionally used in demographic models and in crop-weed competition models. This is probably because growth conditions or cultural practices are often not satisfactorily described or controlled [13].

In this study, we assessed the efficiency of describing black-grass development using classical methods developed for crops such as wheat. The determined base temperature of $1{ }^{\circ} \mathrm{C}$ is in accordance with the ecology of this preferentially winter weed [41], which is capable of early spring germination [36]. Base temperatures change with sowing date [27] and growth conditions. In the literature, base temperatures for weeds are highly variable. A low base temperature $\left(0{ }^{\circ} \mathrm{C}\right)$ has been identified for the germination stage of another winter weed, 

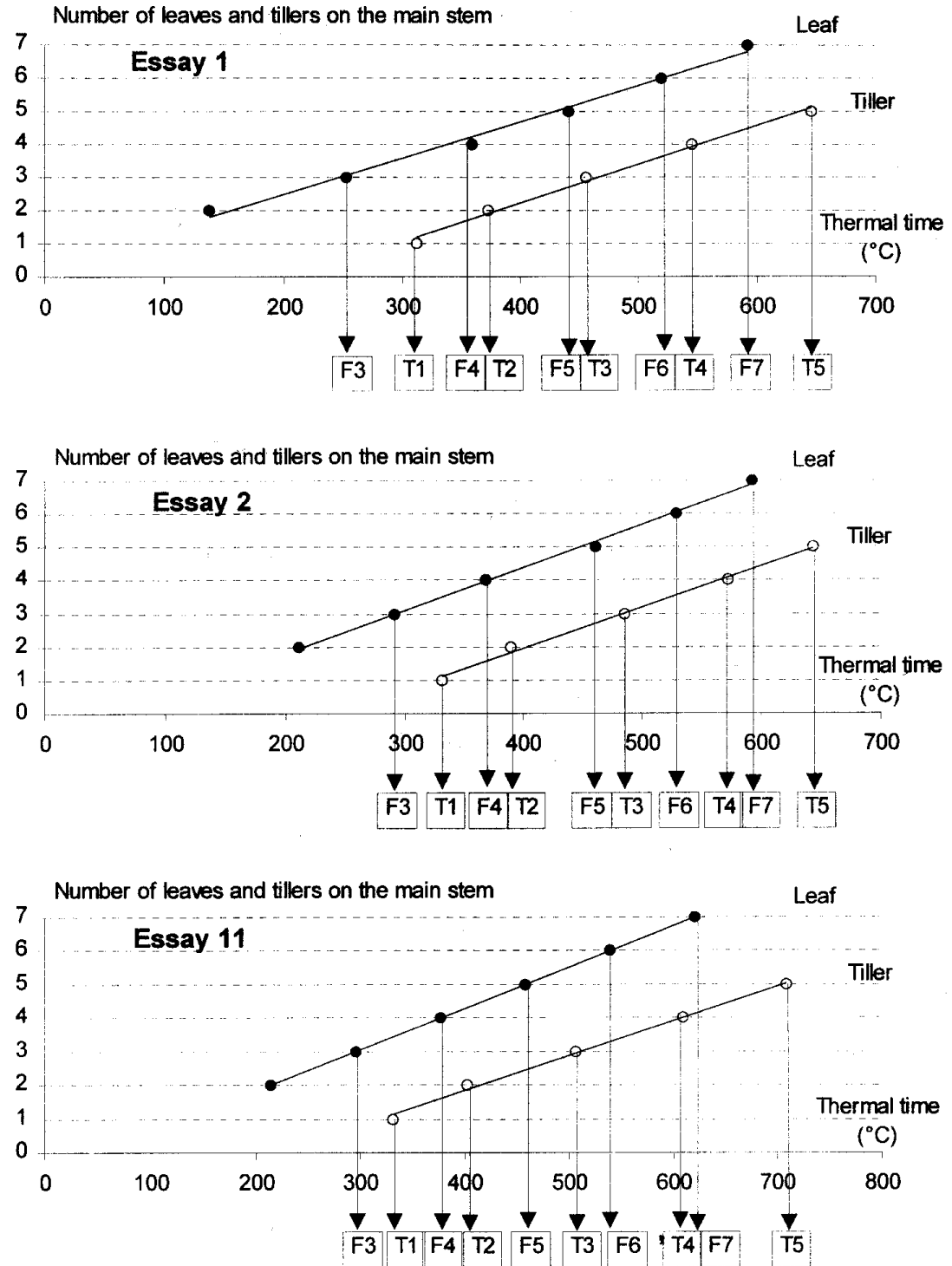

Figure 8. Appearance of leaves $(\mathbf{O})$ and primary tillers $(\bigcirc)$ on the main stem (trials 1,2 and 11) in relation to thermal time (base temperature of $1^{\circ} \mathrm{C}$ ).
Ranunculus repens L. [23]. Generally, the base temperature values selected are rather high (about $\left.10{ }^{\circ} \mathrm{C}\right)$ for summer weeds $(\mathrm{C} 4$ photosynthetic system) such as Amaranthus hybridus L. or Solanum nigrum L. [30] and lower $\left(0\right.$ to $\left.6{ }^{\circ} \mathrm{C}\right)$ for winter and early spring weeds (generally having $\mathrm{C} 3$ photosynthetic systems) such as Chenopodium album [2]. The base temperature of $0{ }^{\circ} \mathrm{C}$ is usually used for forage grasses, annual grass weeds and crops like wheat and barley $[4,16]$. The $1{ }^{\circ} \mathrm{C}$ base temperature for black-grass is also in accordance with gen- eral field observations, which indicate that the vegetative development of this weed occurs during the winter season [36].

Contrary to the data obtained for growth stages $[10,34,36]$, the duration of the developmental stages for black-grass shows low variability between plants. Rates of leaf and tiller development had a low standard error of the mean within a given trial. Our data suggest that there is a variation in leaf appearance with sowing date which 
cannot solely be related to temperature. Certainly, as for cultivated plants, the black-grass phyllochron may be influenced by a number of factors such as water, soil compaction or light [26, 42]. It has been demonstrated that leaf appearance rate varies with sowing date, and that leaves of latesown crop plants generally appear more rapidly [27]. Leaf rate seems to be determined early in the plant life cycle, and is dependent on environmental conditions during the emergence stage [26]. Influence of daylength has also been demonstrated for wheat [9], and other have authors suggested that use of a photothermal scale can improve leaf number prediction [29]. In our case, the relationship of black-grass phyllochron to the thermo/photo ratio scale is lower than for wheat or barley [7]; and in contrast to the data obtained for these same crop species, black-grass phyllochron increases with daylength [7]. Surprisingly, global solar radiation seems to be one of the main factors explaining phyllochron variation in this study. In general, radiation in terms of quality or quantity is described as a factor which influences leaf primordia appearance (plastochron), but which is without effect on leaf appearance (phyllochron) [17, 37]. For black-grass, one hypothesis would be that the appearance of a new leaf, appearing over the ligule of the last leaf, is linked not only to developmental but also to growth processes. As early leaf growth stages (cell multiplication and cell expansion) are influenced by light, the relationship between the phyllochron and global radiation observed in this study could be interpreted as an indirect effect of growth processes. Further studies will have to confirm these preliminary interpretations. Differences in plant vernalization between experiments could also have influenced the black-grass phyllochron, although cold induction does not modify the phyllochron in wheat [8]. In France, A. myosuroides Huds. is a weed that germinates in winter crops such as wheat or rape, and in spring crops such as barley or pea [41]. This ability, which limits the efficiency of control by rotation, occurs simultaneously with a change in the rate of leaf appearance due to sensitivity towards combined environmental factors. The higher appearance rate of black-grass leaves for early spring germination facilitates a faster development and an earlier seed production in spring cereals. This annual weed is suited to produce seeds in either winter crops or spring crops with a lower amount of degree days [10].

The hierarchy of tiller development on the main stem observed for this weed is similar to that observed for wheat [28] or perennial grasses [32]. For wheat, the first tiller appears on the main stem when two leaves are expanded after its subtending leaf [28]. The low shift in appearance of the tillers from the leaves could be explained by the fact that the visual appearance of a new primary tiller emerging from the leaf sheath is physically delayed in comparison with the appearance of a new leaf on the main stem, which is more immediate despite the presence of a rolled shoot. The tiller appearance of black-grass is influenced, similarly to wheat, by several environmental abiotic factors [31] and crop competition. Our studies, both in the field and in the greenhouse, were conducted with low levels of competition for light among plants. For this reason, very few differences in culm appearance were observed.

Leaf and tiller emergence rates could be used to direct herbicide applications $[15,20]$. If new foliar herbicides against grass-weeds are effective on tillered plants, their dosage is strongly linked with the tillering development of the weed. The cumulative temperature after seedling emergence could allow a better estimation of the right time for application and dosage. Low doses of herbicide (subdosages) lead, at least in part, to the development of resistant black-grass populations [18], whereas too high doses of herbicide increase water pollution and cost for farmers.

This study concerns only one sample of blackgrass seeds collected from one field. Other weed populations could display different behavior from that observed in this study. These results provide a basis for future work in modeling black-grass development. Future studies will include the influence of abiotic and biotic factors such as vernalization or genetic effects. The latter will be approached by comparing different populations sampled within fields from several geographic areas with different cropping systems. 
Acknowledgements: $\mathrm{We}$ are grateful to $\mathrm{Mr}$. G. Runser for his technical assistance, and Dr. N. Emery for his help in reviewing the manuscript. We are also greatly indebted to certain anonymous referees for their constructive suggestions.

\section{References}

[1] Allard C., Bill L., Touraud G., L'anthracnose du pois. Revue bibliographique et synthèse, Agronomie 13 (1993) 5-25.

[2] Alm D.M., Pike D.R., Hesketh J.D., Stoller E.W., Leaf area development in some crop and weed species, Biotronics 17 (1988) 29-39.

[3] Arnold C.Y., The determination and significance of the base of temperature in a linear heat unit system, Proc. Am. Soc. Hortic. Sci. 74 (1959) 430-445.

[4] Ball D.A., Klepper B., Rydrych D.J., Comparative above-ground development rates for several grass weeds and cereal grains, Weed Sci. 43 (1995) 410-416.

[5] Barralis G., Ecology of blackgrass (Alopecurus myosuroides Huds.), in: Proc. 9th Br. Weed Cont. Conf., Brighton, England, 1968, pp. 6-8.

[6] Blackshaw R.E., Temperature effects on vegetative growth of round-leaved Mallow (Malva pusilla), Weed Sci. 44 (1996) 63-67.

[7] Cao W., Moss D.N., Temperature and daylength interaction on phyllochron in wheat and barley, Crop Sci. 29 (1989) 1046-1048.

[8] Cao W., Moss D.N., Vernalization and phyllochron in winter wheat, Agron. J. 83 (1991) 178-179.

[9] Cao W., Moss D.N., Sensitivity of winter wheat phyllochron to environmental changes, Agron. J. 86 (1994) 63-66.

[10] Chauvel B., Variabilité de la production de semences chez le vulpin (Alopecurus myosuroides Huds.) en fonction de la culture, in: 10th Int. Conf., Biologie des Mauvaises Herbes, Dijon, France, 1996, pp. 43-49.

[11] Chauvel B., Gasquez J., Influence des facteurs culturaux sur la dynamique du vulpin (Alopecurus myosuroides Huds.), in: Proc. 4th Int. Conf., IFOAM: Maîtrise des Adventices par Voie non Chimique, Dijon, France, 1993, pp. 43-49.

[12] Chauvel B., Runser G., Détermination du taux de viabilité d'un échantillon de semences de vulpin, in:
ANPP, 17th Conf., COLUMA-Journées Internationales sur la Lutte contre les Mauvaises Herbes, Dijon, France, 1998, pp. 31-37.

[13] Colbach N., Debaeke P., Integrating crop management and crop rotation effects into models of weed populations dynamics: a review, Weed Sci. 46 (1998) 717-728.

[14] Durand R., Bonhomme R., Derieux M., Seuil optimal des sommes de températures - application au maïs (Zea mays L.), Agronomie 2 (7) (1982) 589-597.

[15] Forcella F., Banken K. R., Relationship among green foxtail (Setaria viridis) seedling development, growing degree days, and time of nicosulfuron application, Weed Technol. 10 (1996) 60-67.

[16] Frank A.B., Bauer A., Phyllochron differences in wheat, barley and forage grasses, Crop Sci. 35 (1995) $19-23$

[17] Friend D.J.C., Fisher J.E. Helson V.A., The effect of light intensity and temperature on floral initiation and inflorescence development of marquis wheat, Can. J. Bot. 41 (1963) 1663-1674.

[18] Gasquez J., Les graminées résistantes aux herbicides antigraminées en France, ANPP, 17th Conf., COLUMA-Journées Internationales sur la Lutte contre les Mauvaises Herbes, Dijon, France, 1998, pp. 133-140.

[19] Ghersa C.M., Holt J.S., Using phenology prediction in weed management: a review, Weed Res. 35 (1995) 461-470.

[20] Ghersa C.M., Satorre E.H., Van Esso M.L., Pataro A., Elizagaray R., The use of thermal calendar to improve the efficiency of herbicide applications in Sorghum halepense (L.) Pers., Weed Res. 30 (1990) 153-160.

[21] Geslin H., Etude des lois de croissance d'une plante en fonction des facteurs du climat. Contribution à l'étude du climat du blé, thèse, Fac. Sci. Univ. Paris, 1944, pp. 116.

[22] Gilmore Jr E.C., Rogers J.S., Heat units as a method of measuring maturity in corn, Agron. J. 50 (1958) 611-615.

[23] Harris S.M., Doohan D.J., Gordon R.J, Jensen K.I.N., The effect of thermal time and soil water emergence of Ranunculus repens, Weed Res. 38 (1998), 405-412.

[24] Holshouser D.L., Chandler J.M., Wu H., Temperature-dependent model for non-dormant seed germination and rhizome bud break of Johnsongrass (Sorghum halepense), Weed Sci. 44 (1996) 257-265. 
[25] Katz Y.H., The relationship between heat unit accumulation and the planting and harvesting of canning peas, Agron. J. (1951) 74-78.

[26] Kirby E.J.M., Factors affecting rate of leaf emergence in barley and wheat, Crop Sci. 35 (1995) 11-19.

[27] Kirby E.J.M., Appleyard M., Fellowes G., Effect of sowing date and variety on main shoot leaf emergence and number of leaves of barley and wheat, Agronomie 5:2 (1985) 177-126.

[28] Masle-Meynard J., L'élaboration du nombre d'épis chez le blé d'hiver. Influence de différentes caractéristisques de la structure du peuplement sur l'utilisation de l'azote et de la lumière, thèse Docteur-Ingénieur, INA-PG Paris, 1980, pp. 274.

[29] Masle J., Doussinault G., Farquhar G.D., Sun B., Foliar stage in wheat correlates better to photothermal time than to thermal time, Plant Cell Environ. 12 (1989) 235-247.

[30] McGiffen M.E., Masiunas J.B., Prediction of black and eastern black nightshade (Solanum nigrum and $S$. ptycanthum) growth using degree-days, Weed Sci. 40 (1992) 86-89.

[31] McMaster G.S., Phenology, development and growth of the wheat (Triticum aestivum L.) shoot apex: a review, Adv. Agron. 59 (1997) 63-118.

[32] Moore K.J., Moser L.E., Quantifying developmental morphology of perennial grasses, Crop Sci. 35 (1995) 37-43.

[33] Moss S.R., Herbicide resistance in black-grass (Alopecurus myosuroides Huds.), in: Proc. 1987 Br. Crop Prot. Conf.: Weeds, Brighton, England, 1987, pp. 879-886.

[34] Moss S.R., The seed cycle of Alopecurus myosuroides in winter cereals: a quantitative analysis, in: Proc. EWRS Symp. 1990: Integrated Weed Management in Cereals, Helsinki, 1990, pp. 27-36.
[35] Moss S.R., Clarke J., Guidelines for the prevention and control of herbicide resistant black-grass (Alopecurus myosuroides Huds.), Crop Prot. 13 (1994) 381-386.

[36] Naylor R.E.L., Alopecurus myosuroides Huds. (A. agrestis L.): biological flora of the British Isles, J. Ecol. 60 (1972) 611-622.

[37] Rawson H.M., Radiation effects on rate of development in wheat grown under different photoperiods and high and low temperatures, Aust. J. Plant Physiol. 20 (1993) 719-727.

[38] Russo J., Voegele J., Influence de la température sur 4 espèces trichogrammes (Hym., Trichogrammatidae) parasites de la pyrale du maïs, Ostrinia nubilis Hubn. (Lep., Pyralidae) II. Reproduction et survie, Agronomie 2 (6) (1982) 517-524.

[39] SAS Institute Inc., SAS/STAT User's Guide, Version 6, 4th ed., SAS Institute Inc., Cary, NC, USA, 1989.

[40] Satorre E.H., Rizzo F.A. Arias S.P., The effect of temperature on sprouting and early establishment of Cynodon dactylon, Weed Res. 36 (1996) 431-440.

[41] Stryckers J., Delputte P., Biologie et propagation du vulpin des champs Alopecurus myosuroides Huds., Rev. Agric. 8 (1965) 813-836.

[42] Wilhelm W.W., McMaster G.S., Importance of the phyllochron in studying development and growth in grasses, Crop Sci. 35 (1995) 1-3.

[43] Wiese A.M., Binning L.K., Calculating the threshold temperature of development for weeds, Weed Sci. 35 (1987) 177-179.

[44] Zwerger P., Hurle K., Untersuchungen zur relativen Bedeutung einzelner populationsdynamischer Parameter für die Entwicklung der Verunkrautung, Z. Pflanzenkr. Pflantzenschutz 96 (4) (1989) 346-352. 